\title{
Material solidoen deskonposizio termikoan igortzen diren molekula txikien determinazioa mikrouhin- espektroskopiaren bidez
}

\author{
(Determination of small molecules expelled after the thermal \\ decomposition of solid materials through microwave spectroscopy)
}

\author{
Aran Insausti*, Imanol Usabiaga, Maider Parra, Ander Camiruaga, \\ Camilla Calabrese, Emilio J. Cocinero \\ Zientzia eta Teknologia Fakultatea (UPV-EHU), Leioa, Bizkaia \\ Biofisika Institutoa (CSIC/UPV-EHU), Leioa, Bizkaia
}

LABURPENA: Mikrouhin-espektroskopiaren (MW) oinarriak eta sistema esperimentalen oinarrizko funtsak emanez, materialen deskonposizio termikoetan gas eran igortzen diren molekula txikien determinazio kualitatiboa burutu daitekeela frogatu da. Adibide modura, errotazio-espektroskopiaren eta hedapen supersonikoaren konbinaketaren bidezko etorkizuneko eguzki-zeluletan erabil daitekeen metilamonio berun triioduroa $\left(\mathrm{CH}_{3} \mathrm{NH}_{3} \mathrm{PbI}_{3}\right)$ perovskiten deskonposizio termikoan sortzen diren molekula txikien determinazio zehatza egin da. Lortutako emaitzak aurretik bestelako teknikekin lortutako emaitzekin bat datozela ikusi da, prozedura honen baliagarritasuna erakutsiz eta mikrouhin-espektroskopia teknika analitiko moduan erabil daitekeela erakutsiz.

HITZ GAKOAK: Errotazio-espektroskopia, degradazioa, pirolisi, perovskita, mikrouhin-espektroskopia.

ABSTRACT: The qualitative determination of small molecules that reach the gas phase after the thermal decomposition of solar cell materials, have been carried out by means of microwave spectroscopy $(M W)$. In this case, the evidence of small molecule tracers after the thermal decomposition of pervoskites $\left(\mathrm{CH}_{3} \mathrm{NH}_{3} \mathrm{PbI}_{3}\right)$ has been proved thanks to the combination between rotational spectroscopy and supersonic expansion. The results are in good agreement with those previously obtained from other techniques, and this demostrates the ability of microwave spectroscopy to perform satisfactorly as analytical tool.

KEYWORDS: Rotational-spectroscopy, degradation, pirolysis, perovskite, microwave spectroscopy.

\footnotetext{
* Harremanetan jartzeko / Corresponding author: Aran Insausti Beiro. Zientzia eta Teknologia Fakultatea (UPV-EHU) eta Biofisika Institutoa (CSIC-EHU), Sarriena auzoa, 48940 Leioa. - aran.insaustib@ehu.eus - https://orcid.org/0000-0002-9291-1762

Nola aipatu / How to cite: Insausti, Aran; Usabiaga, Imanol; Parra, Maider; Camiruaga, Ander; Calabrese, Camilla; Cocinero, Emilio J. (2021). "Material solidoen deskonposizio termikoan igortzen diren molekula txikien determinazioa mikrouhin-espektroskopiaren bidez». Ekaia, 40, 2021, 247-258. (https://doi.org/10.1387/ekaia.21859).

Jasotze-data: 2020, ekainak 29; Onartze-data: 2020, abenduak 7.
}

ISSN 0214-9753 - elSSN 2444-3581 / (c) 2021 UPV/EHU

(c) (i) $\odot$ Lan hau Creative Commons Aitortu-EzKomertziala-LanEratorririkGabe 4.0 Nazioartekoa lizentzia baten mende dago 


\section{SARRERA}

Azken aldiko energiaren eskari-igoerak eta erregai fosiletan oinarritutako energiaren jaitsierak iturri berriztagarrietan oinarritutako energiaren erabilpenean jarri du arreta. Energia berriztagarriak eskuratzeko metodo desberdinen artean, garrantzitsuenetarikoak eguzki-energian du oinarri; zeinek zuzenean eguzki-erradiazioa energia elektriko bilaka dezakeen. Metilamonio berun trihaluro $\left(\mathrm{MAPbX}_{3}\right)$ perovskiten propietateak, etorkizuneko eguzki-zeluletan erabiltzeko material potentziala dela ikusi da [1]. Azken urteetan $\mathrm{MAPbX}_{3}$ materialen efizientzia esponentzialki garatu da, eta \% 20 baino gehiagoko bihurketa-efizientzia potentziala lortzera iritsi da [2]. $\mathrm{MAPbX}_{3}$ eguzki-zelulen arazo nagusia bere egonkortasun baxuan dago, kontuan hartuz materialaren iraunkortasuna ezinbestekoa dela bere erabilera komertziala bultzatzeko [3].

Materialen egonkortasuna aztertzeko, degradazio termikoa metodo oso erabilia da [4]. Egunotan, teknika ugarik ahalbidetzen dute material solidoen konposizio, egitura edo propietateak tenperaturarekiko duen dependentzia ezagutzea. Konposatu solidoan gertatzen diren aldaketak informazio ugari ematen du. Hala ere, degradazio termikoan gas eran askatzen diren konposatuak ezagutzea funtsezkoa da, deskonposizio baten mekanismoa ezagutzeko, adibidez. Pirolisi edo deskonposaketa termikoan, atmosfera espezifiko batean igortzen diren gasen analisia egiteko teknikarik erabilienak dira termo-grabimetria (TG) eta analisi termiko diferentzial (DTA) esperimentuei akoplatutako masa-espektrometria (MS) eta infragorri-espektroskopia [5, 6]. Teknika horien erabilera hedatua dagoen arren, tenperatura desberdinetan solido batek igortzen dituen molekulak identifikatzeko, TG-MS-ren eskuragarritasuna ez da erraza, eta ioien informazioaren bidez konposatu bat identifikatzea ez da beti bideragarria: isomeroetan, adibidez. Gainera, bibrazio-espektroskopiak ez du beti ahalbidetzen molekulen identifikazio zehatza lortzea, batez ere tenperatura finko batean zenbait konposatu aldi berean askatzen direnean.

Metilamonio berun triioduro $\left(\mathrm{CH}_{3} \mathrm{NH}_{3} \mathrm{PbI}_{3}\right)$ perovskita, adibidez, etorkizuneko eguzki-zelulak egiteko material potentziala den arren, bere egonkortasun txikia dela eta, oraindik ez da erabilera errentagarria duen materialik lortu [7]. Izan ere, deskonposizioaren ondorioz lortzen diren produktuen propietateek zelula fotovoltaikoen efizientzia zeharo jaitsi egiten dute [8]. Hori dela eta, haren egonkortasun termikoa asko ikertu da azken urteetan. $\mathrm{CH}_{3} \mathrm{NH}_{3} \mathrm{PbI}_{3}$ perovskitaren degradazioan bi mekanismo posible (1. eta 2. erreakzioak) aurreikusita zeuden [9].

$$
\begin{aligned}
& \mathrm{CH}_{3} \mathrm{NH}_{3} \mathrm{PbI}_{3}(\mathrm{~s}) \rightarrow \mathrm{NH}_{2} \mathrm{CH}_{3}(\mathrm{~g})+\mathrm{HI}(\mathrm{g})+\mathrm{PbI}_{2}(\mathrm{~s}) \\
& \mathrm{CH}_{3} \mathrm{NH}_{3} \mathrm{PbI}_{3}(\mathrm{~s}) \rightarrow \mathrm{NH}_{3}(\mathrm{~g})+\mathrm{CH}_{3} \mathrm{I}(\mathrm{g})+\mathrm{PbI}_{2}(\mathrm{~s})
\end{aligned}
$$


Bi mekanismoetan, solido gisa gelditzen den konposatua berdina da, $\mathrm{PbI}_{2}$. Hori dela eta, solidoa bakarrik aztertuta degradazio-prozesuaren mekanismo zehatza ezagutzea ez da guztiz bideragarria. Hala ere, atmosfera geldoan kiskaltze-prozesuan igortzen diren gasak identifikatuz, erreakzioaren mekanismoa ezagutu daiteke. Hori ikusita, hainbat ikertzaile, teknika desberdinak erabiliz, deskonposizioan igortzen diren gasak identifikatzen ahalegindu dira $[9,10]$. Azkenean, DTA-MS konbinazioaren bidez, atmosfera geldoan, $200^{\circ} \mathrm{C}$ inguruan $\mathrm{CH}_{3} \mathrm{I}$ eta $\mathrm{NH}_{3}$ gasak $\mathrm{CH}_{3} \mathrm{NH}_{3} \mathrm{PbI}_{3}$ perovskitaren degradazio termikoan igortzen direla egiaztatu zuten [11]. Beraz, proposatutako lehenengo mekanismoa (1. erreakzioa) gertatzen dela ondorioztatu zuten (ikusi 1. irudia). Lan horretan MS emaitzek $\mathrm{CH}_{3} \mathrm{NH}_{2}$ eta $\mathrm{HI}$ konposatuak degradazio-prozesuan parte har dezaketela zirudien arren, erabilitako DTA -MS-k ez zuen ahalbidetu haien determinazio zehatza lortzea.
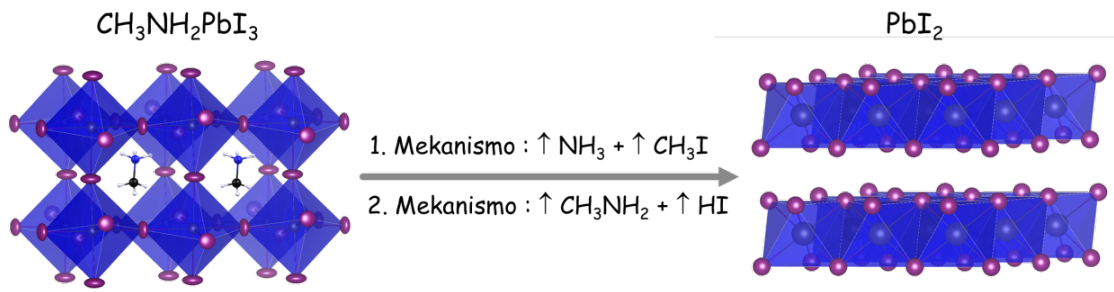

1. irudia. $\mathrm{CH}_{3} \mathrm{NH}_{3} \mathrm{PbI}_{2}$ perovskitaren degradazioa. Solido produktua berdina den arren, gertatzen den degradazio-mekanismoaren arabera gas desberdinak askatzen dira.

Lan honen helburua da lehenengoz espektroskopia errotazionala erabiliz material honen degradazioarena karakterizazioa nola egin daitekeen azaltzea. Sistema esperimental bakoitzaren abantailak jakinda, $\mathrm{CH}_{3} \mathrm{NH}_{3} \mathrm{PbI}_{3}$ perovskiten deskonposizio termikoan igortzen diren molekulen identifikazioa egingo da. Azkenean, espektroskopia errotazionala material desberdinen deskonposizio termikoan igorritako molekula txikien identifikazio zehatza egiteko teknika berria bezala aurkezten da.

\section{ERROTAZIO-ESPEKTROSKOPIAREN OINARRIAK}

Errotazio-espektroskopia molekularrak frekuentzia baxuko erradiazio elektromagnetikoa erabiltzen du. Batez ere, espektro elektromagnetikoko mikrouhinen gunekoa, molekulen kuantizatutako maila zinetiko errotazionalak kitzikatzeko. Maila zinetiko errotazionalen energia-patroiak molekularen inertzia-momentu nagusiekin determina daitezke. Inertzia momentuak molekulek masa zentroarekiko duen masen (atomoen) ba- 
naketarekin zuzenean erlazionatuta daude. Beraz, lortutako datu espektroskopikoak molekulen hiru dimentsioko egituraren informazio zehatza ematen du. Horri esker, espektroskopia errotazionala da konformero, isomero eta isotopomeroen analisia egiteko gaur egun dagoen teknikarik zehatzena [12].

Teknika espektroskopiko honek aplikazio desberdinak ditu kimikaren zenbait arlotan. Molekula eta konplexu txikien egitura intrintsekoen identifikazioak oinarrizko kimikaren ezagutza zabaltzeko balio du. Molekulen egitura zehaztasun atomikoarekin jakiteak molekulen arteko interakzio ahulei buruzko (van der Waals indarrak, $\pi-\pi$ pilaketa, H-loturak) informazioa ere ematen du [13]. Teknika esperimental hau, atomoen kokapenarekiko duen sentsibilitatea dela eta, kalkulu konputazionalen zehaztasuna kudeatzeko ere erabil daiteke [14]. Horretaz gain, molekula bakoitzaren errotazio-espektroa bere hatz-marka bezalakoa denez, oso erabilgarria da bai karakterizazio analitikoak egiteko eta baita, astrokimikan, espazioan dauden molekulak identifikatzeko ere [15].

Trantsizio errotazionalen hautaketa-arauen arabera, ezinbestekoa da molekulak edo konplexuak momentu dipolar iraunkorra izatea. Horretaz gain, iker daitezkeen sistemen tamaina nahiko mugatuta dago, eta gehienez 20 atomo pisutsu ( $\mathrm{H}$ atomoak kontutan izan barik) inguruko sistemak identifikatzeko sentsibilitatea du teknikak. Sistema edo molekula txikiek frekuentzia handiagoko alde espektroskopikoan agertuko dira, eta molekula handiagoak, aitzitik, frekuentzia baxuagoko aldean. Hori dela eta, ikertu nahi diren molekulak ezagututa, aldez aurreko zenbait kalkulu beharrezkoak dira mikrouhin-espektrometroaren frekuentzien tartea zuzen hautatzeko.

Ohiko molekula organikoen errotazio-espektro asko aurretiaz neurtuta daude, eta haien trantsizioak zenbait datu-basetan eta argitaratutako artikuluetan aurkitu daitezke $[16,17]$. Horri esker, datu aproposak eskuratuta eta oinarrizko errotazio-ezagutzak kontuan izanda, aurretik neurtuta dauden molekulen identifikazioa edonork egin dezake errotazio espektro bat lortuz gero. Emaitzetan ikusiko den moduan, tenperatura desberdinetan neurtutako espektro errotazionala izanez gero, material baten degradazio termikoan igorritako molekula txikien identifikazioa erraz egin daiteke, baldin eta haren trantsizio errotazionalak ezagunak badira.

\section{MIKROUHIN-ESPEKTROMETROAK}

Mikrouhin (MW) espektrometroak, erabiltzen duten detekzio-metodoaren arabera, bi talde nagusitan sailkatu daitezke: absortzio eta emisio molekularrean oinarritutakoak. MW sistema klasikoak molekulen absortzioan oinarritzen dira. Oro har, frekuentzia altuan egiten dute lan, eta lagina gor- 
dailu baten barnean gas eran dagoelarik aztertzen da. Frekuentzia altuetan lan egiten dutenez, oro har molekula txikien errotazio-espektroak lortzeko erabiltzen dira.

Izpi molekular supersonikoaren bidez, trantsizio errotazionalen emisioan oinarritutako esperimentuetan aurrerapen handia izan zen. Izpi molekular supersonikoa lortzeko, presio atmosferikoan edo altuagoan dagoen gas bat, zirrikitu txiki baten bidez ganbara huts batekin konektatu behar da $\left(10^{-7} \mathrm{mbar}\right)$. Espantsio supersonikoa gasa behin zirrikitutik pasa ondoren ganbara hutsean zabaltzean gertatzen da. Hutsean zabalduko den gasa, ikertu nahi den molekulaz eta gas garraiatzaileaz (normalean gas geldoa $\mathrm{He}$, Ne edo Ar) konposatuta egongo da. Molekulen espantsio supersonikoa egoera berezia da. Hau zirrikitutik ganbara hutsean zabaltzean gas geldoaren eta molekulen atean gertatu diren talka kopuru handiaren ondorioa da. Talka horien ondoren, molekulak eta eratutako konplexuak talkarik gabe higitzen dira norantza paraleloan, ingurunetik eta molekula bata bestetik isolatuta egongo balira bezala, nolabaiteko gas fase berezi bat lortzen delarik. Espantsio-prozesua adiabatikoa da eta horren ondorioz molekulak hozketa izugarria jasaten dute, $\sim 2-5 \mathrm{~K}$ errotazional lortu arte. Laburbilduz, molekula isolatu eta izoztuak (oinarrizko maila errotazionalean) lortzen dira.

Flygare eta Ballek trantsizio errotazionalak molekulen izpi molekular supersonikoaren emisiotik jasotzeko lehenengo errotazio espektrometroa diseinatu zuten. Sistema honetan izpi molekular supersoniko baten bidez hoztu eta isolatutako molekulak Fabry-Pérot interferometro batean islatzen den mikrouhinen erradiazioarekin kitzikatzen dira, azkenik molekulek igorritako erradiazioa denbora domeinuan jasoz [18]. Espektrometro hau sentsibilitate eta erresoluzio handieneko $(\sim 5 \mathrm{kHz})$ esperimentua da. Hala ere, interferometroaren barrunbe diseinuak, frekuentzia (uhin-luzera) bakoitzerako ganbara hutsaren barruko aluminiozko ispiluen distantzia optimizatu beharra dago, eta, horren ondorioz, denbora luzea behar da espektroaren frekuentzia-tarte zabala eskuratzeko.

Interferometroan oinarritutako ekipoen denbora esperimentala murrizteko asmoz, 2007. urtean, Brooks Pate-ren taldeak (Virginiako Unibertsitatea) izpi molekular supersonikoan potentzia handiko multifrekuentzia pultsuan (chirp) oinarritutako espektrometroa garatu zuen, zeinek espektro elektromagnetikoaren banda zabal bat esperimentu batean jaso dezakeen [19]. Sistema honetan, MW frekuentzia-tarte zabal bat kitzikatu eta molekulen emisioa prestakuntza handiko osziloskopio batekin eskuratzen $\mathrm{da}, \sim 20 \mathrm{kHz}-\mathrm{ko}$ erresoluzio espektralarekin.

Euskal Herriko Unibertsitateko (UPV/EHU) errotazio-espektroskopiako taldeak, Flygare-Balle eta chirp espektrometroak eraiki ditu azken 10 urteetan, eta puntako ikerketa-taldea sortu du. 

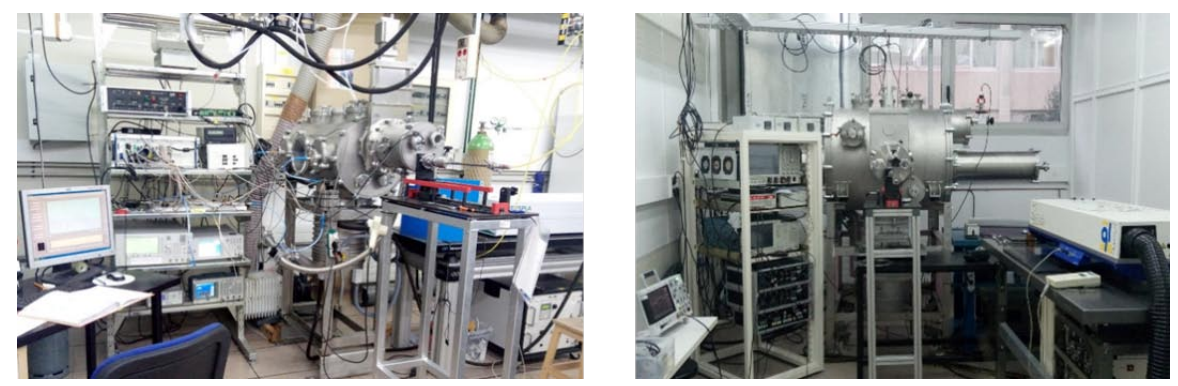

2. irudia. EHU/UPVn eraikitako mikrouhin-espektrometroak. Ezker aldean, Flygare-Balle diseinuan oinarritutako esperimentua, eta eskuinean, chirp esperimentua.

\section{EMAITZAK}

$\mathrm{CH}_{3} \mathrm{NH}_{3} \mathrm{PbI}_{3}$ perovskita-laginak atmosfera geldoan pirolizatuz igortzen dituen molekulak espektroskopia errotazionalaren bidez identifikatu dira. 1. eta 2. erreakzioen arabera, $\mathrm{CH}_{3} \mathrm{NH}_{3} \mathrm{PbI}_{3}$ perovskiten degradazioan gertatzen den mekanismoaren arabera, $\mathrm{NH}_{3}, \mathrm{CH}_{3} \mathrm{I}, \mathrm{HI}$ eta $\mathrm{CH}_{3} \mathrm{NH}_{2}$ konposatuak aska daitezke. Gas hauek guztiek momentu dipolar iraunkorra dute; beraz, printzipioz errotazionalki aktiboak dira. Molekula arruntak direnez, aurretik haren espektro errotazionalak bilatu dira bibliografian, eta EHUko instrumentuaren frekuentzia-erabilera tartean $(2-18 \mathrm{GHz}) \mathrm{CH}_{3} \mathrm{I}$ eta $\mathrm{CH}_{3} \mathrm{NH}_{2}$ identifika daiteezkela ikusi da. Izan ere, $\mathrm{CH}_{3} \mathrm{NH}_{2}$ trantsizio-patroi ezaugarri bat du $8780 \mathrm{MHz}$ inguruan, eta $\mathrm{CH}_{3} \mathrm{I}$ hiru seinale nahiko bereizgarri ditu, 14694.93, 15100.74 eta 15275.89 MHz-tan [20,21]. Seinale kopurua txikia den arren, erresoluzio espektrala (erabilitako chirp instrumentoan $20 \mathrm{kHz}$ inguru) eta seinaleen arteko intentsitate-proportzioarekin haien identifikazio zehatza lor daiteke. Degradazio-prozesuan igor daitezkeen bestelako molekulen errotazio-seinaleak gure sistema esperimentalaren frekuentzietatik kanpo daude, HI-ak $385 \mathrm{GHz}$ dauka bere lehenengo trantsizioa eta $\mathrm{NH}_{3}-\mathrm{k} 572 \mathrm{GHz}-\tan [22,23]$.

Aurretik neurtutako molekulen identifikazioa egiteko nahitaezkoa den arren, interesgarria da informazio bibliografikoa berrikustea. Kasu honetan, identifikatu nahi diren molekulen kalkulu mekano-kuantikoak egin dira, hauek lortutako datuekin alderatuta ikuspuntu global bat eratzeko aukera ematen baitu. Gainera, zenbait kontzeptu ulertzeko baliagarriak dira. 3. irudian ikus daitekeen moduan, $\mathrm{CH}_{3} \mathrm{NH}_{2}$ eta $\mathrm{CH}_{3} \mathrm{I}$ molekulak egoera isolatuan duten geometria optimizatuak irudikatu dira, B3LYP/def2-QZVP kalkulumaila erabilita.

Bi molekula hauek, izpi molekular supersonikoak ahalbidetzen duen egoera isolatuan, konformero egonkor bakarra dute, eta horren ondorioz, 
errotazio-espektroan bakarrik konformero horren informazioa dago bilduta. Izpi molekular supersonikoan ikusten diren konformeroak, oro har, molekularen egitura intrintsekoaren informazioa dute. Hala ere, antzeko energia duten konformero desberdinak zehazki identifika daitezke, haien arteko energia-desberdintasun erlatiboa $<5-10 \mathrm{~kJ} / \mathrm{mol}$ inguru denean [24]. Izan ere, atomoen kokapenak molekularen inertzia-momentu nagusiekiko eta, noski, errotazio konstanteekiko duen dependentzia oso handia da.
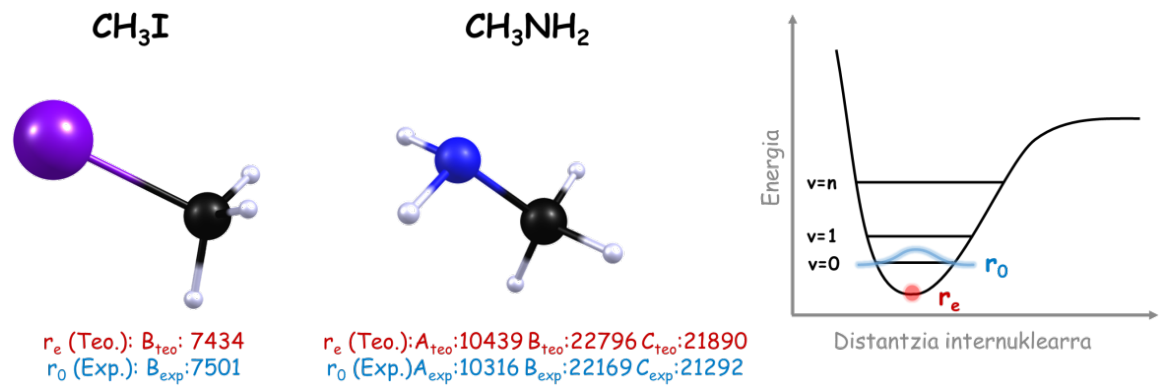

3. irudia. Esperimentalki UPV/EHU mikrouhin-espektrometroan $\mathrm{CH}_{3} \mathrm{NH}_{3} \mathrm{PbI}_{2}$ perovskitaren degradazioan detekta daitezkeen molekulen egiturak B3LYP/defQZVP kalkulu mekano-kuantikoekin optimizatuta. Gorriz, molekula bakoitzaren trantsizio teorikoak, eta urdinez, bibliografian topatutako trantsizio errotazional esperimentalak $[20,21]$. Eskuinean, teorikoki eta esperimentalki determina daitezkeen konformeroen energia-diagrama.

Emaitza teoriko eta bibliografikoak aztertuz, ikus daiteke errotaziokonstante teorikoak eta esperimentalak alderatzen diren arren ez datozela guztiz bat; gainera, hau orokorrean behatzen den gertaera da. Molekula isolatuen kalkulu kimiko-kuantikoak ematen duten geometria $\left(r_{e}\right)$ oreka-geometria delako gertatzen da (3. irudia). Aitzitik, esperimentalki lortzen dena, oro har, $\left(\mathrm{r}_{0}\right) \mathrm{v}=0$ bibrazio-mailan dagoen egiturarena da (3. irudia). Beraz, aipatu beharra dago identifikatuta ez dagoen molekula baten detekzioa egitea ez dela gauza tribiala; alegia, aldez aurretik trantsizio errotazionalen esleipena beharrezkoa da. Azkenik, errotazio espektroaren intentsitatea, besteak beste, molekulak ardatz bakoitzarekiko duen momentu dipolarrarekin zuzenki erlazionatuta dago, eta oro har seinale intentsoenak momentu dipolar handiena duen ardatzean izaten dira.

Neurketa egiteko erabilitako sistema esperimentala, Euskal Herriko Unibertsitatean eraikitako eta $7.5-18 \mathrm{GHz}$ frekuentzia-tartean lan egiten duen chirp espektrometroa da (4. irudia). Instrumentu hori, Pate taldearen aparatuaren diseinuan oinarrituta dago. Espektroa eskuratzeko, chirp erradiazioa uhin arbitrario sorgailu (Arbitrary Waveform Generator, $24 \mathrm{Gs} / \mathrm{s}$ ) batekin sortu eta uhin progresiboko hodi (TWT, Travelling- 
Wave Tube, $250 \mathrm{~W}$ ) baten bidez anplifikatu da. Uhina, tanke hutsean antena baten bidez sartu da, izpi molekular supersonikoan dauden molekulak errotazionalki kitzikatzeko. Azkenik, molekulen emisioa 20 mikrosegundoko denbora tartean, $100 \mathrm{Gs} / \mathrm{s}$ osziloskopio baten bidez eskuratu da. Molekulen emisioa denbora domeinutik frekuentzia domeinura pasatzeko, Fourierren transformatua erabili da. Sistema esperimentalaren eskema 4. irudian ikus daiteke.

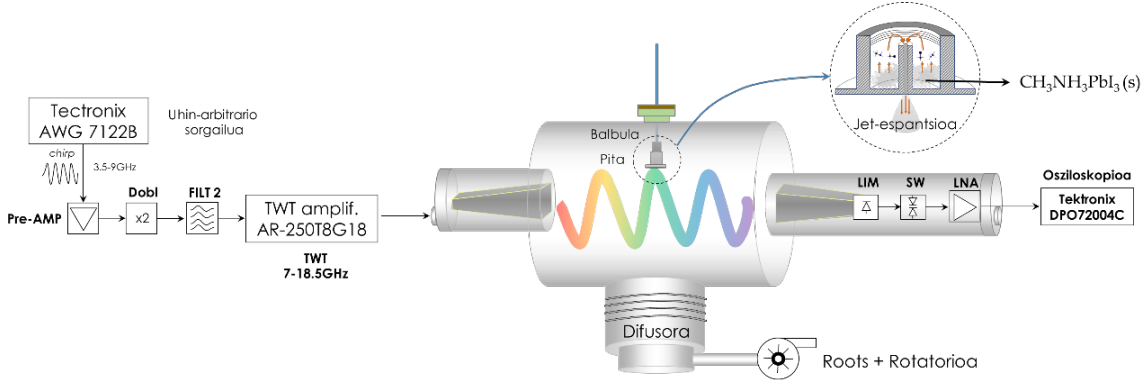

4. irudia. Erabilitako sistema esperimentalaren eskema. Ezker aldean, molekulak kitzikatzeko elektronika: AWG 7122B uhin sorgailua; Pre-AMP, erradiazio aurreanplifikagailua; Dobl, bikoiztailea; Filt, uhin iragazkia eta TWT AR-250T8G18, potentzia handiko anplifikagailua. Eskuin aldean, molekulen emisioa detektatzeko elektronika: LIM, potentzia geldigailua; SW, etengailua; LNA, zarata baxuko anplifikagailua eta Tektronix DPO72004C osziloskopioa. Esker aldean goian lagina sartzeko pitaren eskema irudikatu da.

$\mathrm{CH}_{3} \mathrm{NH}_{3} \mathrm{PbI}_{3}$ perovskita hauts polikristalino lagina, bertan diseinatutako gordailu-pita batean sartu eta pultsuzko balbula batean jarri da (4. irudia). Gordailu-pita, beroketa-erresistentzia eta termopare bat digitalki tenperatura kontrolatzen duen sistema batera konektatuta dago. Haren tenperatura-erabileraren tartea ingurugiroko tenperaturatik $300^{\circ} \mathrm{C}$-rainokoa da. Gas garraiatzaile eta pirolisi atmosfera moduan, He erabili da 1 bar presioarekin.

5. irudiko tenperatura maldaren bidez, tenperatura desberdinetan berotutako laginak igorritako molekulen errotazio-espektroa eskuratu da. Aurreikusia zegoen moduan, eta 5. irudiko espektroen arabera, $200^{\circ} \mathrm{C}$ inguruan $\mathrm{CH}_{3} \mathrm{NH}_{3} \mathrm{PbI}_{3}$-ren deskonposizioa hasten da; izan ere, tenperatura horretan berotutako laginaren errotazio espektroan $\mathrm{CH}_{3} \mathrm{I}$ eta $\mathrm{CH}_{3} \mathrm{NH}_{2}$ gasen seinale adierazgarriak molekula hauek laginetik askatzen direlako ondorioa zuzena da. $230^{\circ} \mathrm{C}$ inguruan deskonposizio-seinaleak oso nabariak zirenez, espektroa 70 ordutan zehar bildu da, seinale/zarata optimoa duen espektroa eskuratzeko eta deskonposizio-prozesuan ager litezkeen aurretik ez identifikatutako bestelako konposatuak igortzen diren ikusteko. 


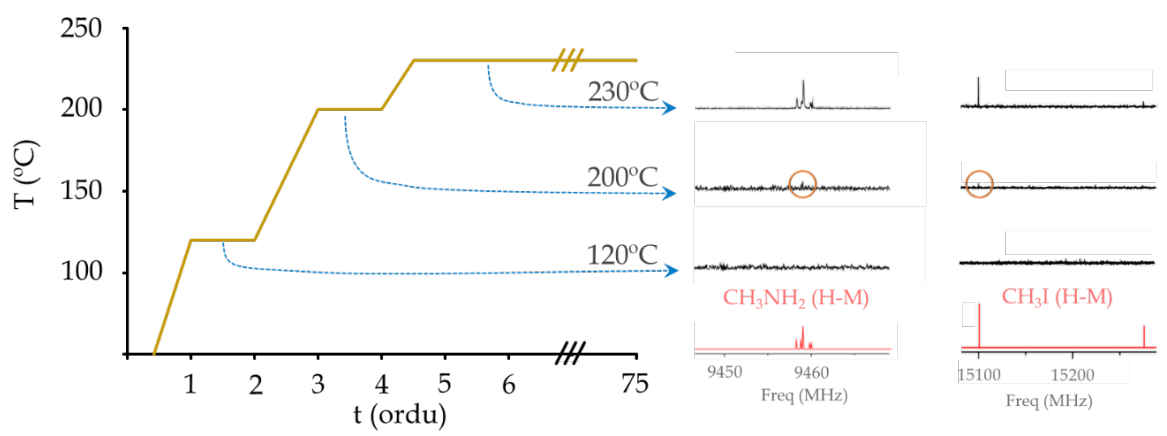

5. irudia. Tenperatura desberdinetan eta denbora-tarte desberdinetan lortutako $\mathrm{CH}_{3} \mathrm{NH}_{2}$ eta $\mathrm{CH}_{3} \mathrm{I}$ molekulen espektro errotazionalaren zatia.

Espektroa ikusita, alde batetik, gure lan-frekuentzia tartean identifika daitezkeen espezieen artean nagusiki sortzen diren gasak $\mathrm{CH}_{3} \mathrm{I}$ eta $\mathrm{CH}_{3} \mathrm{NH}_{2}$ direla ikusi da; izan ere, ez zen bestelako seinale nabaririk ikusten espektroan. Horren arabera, $\mathrm{CH}_{3} \mathrm{NH}_{3} \mathrm{PbI}_{3}$ degradazio-prozesuan proposatutako bi mekanismoak aldi berean gertatzen dira. Beste alde batetik, ez da posible aipatutako gasen kuantifikaziorik ez eta haien arteko proportzioen determinaziorik egitea, kontuan hartuz errotazio-espektroskopiaren bitartez lortutako seinaleen intentsitatean faktore askok dutela eragina (momentu dipolarrak, trantsizio motak, molekularen hozketak jet supersonikoan, konformero kopuruak...). Hala ere, aurretik ikusita zegoen moduan, errotazio-espektroskopiaren bidez $200^{\circ} \mathrm{C}$ inguruan $\mathrm{CH}_{3} \mathrm{NH}_{3} \mathrm{PbI}_{3}$ perovskitaren degradazio termikoa atmosfera geldoan hasten dela ziurtatu da. Identifikatutako bi gasek ziurtatzen dute proposatutako bi degradazio-mekanismoak aldi berean gertatzen direla. Beraz, esperimentu honen bidez, frogatu da errotazio-espektroskopia pirolisi edo degradazio termiko prozesu batean gas eran igortzen diren gasak detekta daitezkeela.

\section{ONDORIOAK}

MW espektroskopia teknika eraginkorra dela bermatu da konposatu desberdinen degradazio termikoan igortzen diren gasen determinazio kualitatiboa egiteko. Teknika honen bidez, bestelako tekniken bidez ez bezala, molekulen determinazio zehatza burutu daiteke. Tenperatura desberdinetan espektro errotazionala egiteko baliabideak guztiz eskura ez dauden arren, UPV/EHUn bertan eraikitako espektrometroak daude eta datu-baseetako informazioa eta oinarrizko mikrouhin-espektroskopia ezagututa, pirolisi-erreakzioan askatzen diren gasen identifikazio erraza egin daiteke. 
Emaitzetan ikusi den moduan, aztertutako $\mathrm{CH}_{3} \mathrm{NH}_{3} \mathrm{PbI}_{3}$ perovskitaren degradazio termikoa MW espektroskopiaren bidez egin daiteke. Teknika honen bereizmenari esker, aurretik egindako ikerketetan ikusitako 1 erreakzioko degradazioaren mekanismoaz gain, 2 erreakzioko degradazio-mekanismoa aldi berean gertatzen dela ikusi da, hau da, pirolisi-prozesuan materialetik $\mathrm{CH}_{3} \mathrm{I}$ eta $\mathrm{CH}_{3} \mathrm{NH}_{2}$ konposatuak gas eran askatzen dira. Horretaz gain, eskuratutako espektroan ez zen bestelako seinale nabarmenik ikusi; hortaz, degradazioa ziurrenik soilik proposatutako bi degradazio-mekanismoen bidez gertatzen da.

\section{ESKER ONAK}

Eskerrak ematen dizkiogu MINECOri (CTQ2017-89150-R), Eusko Jaurlaritzari (IT1162-19) eta UPV/EHUri (PPG17/10, GIU18/207) laguntza ekonomikoarengatik. A.I.-k eta A.C.-k eskertzen dute Eusko Jaurlaritzak emandako laguntza ekonomikoa doktorego tesia egiteko, eta M.P.-k Euskal Herriko Unibertsitateak (UPV/EHU) emandako diru-laguntza doktorego tesia egiteko. I.U.-k (UPV/EHU) Euskal Herriko Unibertsitateak emandako doktoretza-ondoko laguntza ekonomikoagatik. Azkenik, eskerrik asko SGIKER (UPV/EHU) konputazio eta laser zerbitzuari.

\section{BIBLIOGRAFIA}

[1] Kojima, A., Teshima, K., Shirai, Y., Miyasaka, T. 2009. «Organometal Halide Perovskites as Visible-Light Sensitizers for Photovoltaic Cells». Journal of the American Chemical Society, 131, 6050-6051.

[2] Kim, H. S., Hagfeldt, A., PARK, N. G. 2019. «Morphological and compositional progress in halide perovskite solar cells». Chemical Communications, 55, 1192-1200.

[3] YAng, Y., You, J. 2017. «Make perovskite solar cells stable». Nature, 544, 155-156.

[4] Plante, A. F., Fernández, J. M., Leifeld, J. 2009. «Application of thermal analysis techniques in soil science». Geoderma, 153, 1-10.

[5] Boguta, P., SokoŁowska, Z., Skic, K. 2017. «Use of thermal analysis coupled with differential scanning calorimetry, quadrupole mass spectrometry and infrared spectroscopy (TG-DSC-QMS-FTIR) to monitor chemical properties and thermal stability of fulvic and humic acids». PLOS ONE, 12, 1-18.

[6] Li, T., Song, F., Zhang, J., LiU, S., Xing, B., BAI, Y. 2019. «Pyrolysis characteristics of soil humic substances using TG-FTIR-MS combined with kinetic models». Science of the Total Environment, 698, 134237.

[7] Ava, T. T., Al Mamun, A., Marsillac, S., Namkoong, G. 2019. «A review: Thermal stability of methylammonium lead halide based perovskite solar cells». Applied Sciences, 9, 188. 
[8] Huang, W., Sadhu, S., Ptasinska, S. 2017. «Heat- and Gas-Induced Transformation in $\mathrm{CH} 3 \mathrm{NH} 3 \mathrm{PbI} 3$ Perovskites and Its Effect on the Efficiency of Solar Cells». Chemistry of Materials, 29, 8478-8485.

[9] U, H., Wang, F., Xie, F., Li, W., Chen, J., Zhao, N. 2014. «The Role of Chlorine in the Formation Process of " $\mathrm{CH} 3 \mathrm{NH} 3 \mathrm{PbI} 3-\mathrm{x} \mathrm{Cl}$ x" Perovskite». Advanced Functional Materials 1-7.

[10] Dualeh, A., Gao, P., Seok, S. Il, Nazeeruddin, M. K., Grätzel, M. 2014. «Thermal behavior of methylammonium lead-trihalide perovskite photovoltaic light harvesters». Chemistry of Materials, 26, 6160-6164.

[11] Juarez-Perez, E. J., Hawash, Z., Raga, S. R., Ono, L. K., QI, Y. 2016. «Thermal degradation of $\mathrm{CH} 3 \mathrm{NH} 3 \mathrm{PbI} 3$ perovskite into NH3 and $\mathrm{CH} 3 \mathrm{I}$ gases observed by coupled thermogravimetry-mass spectrometry analysis». Energy and Environmental Science, 9, 3406-3410.

[12] Gordy, W., CoOK, R. L. 1984. Microwave Molecular Spectra. New York, Chichester, Brisbane, Toronto, Singapore.

[13] Calabrese, C., Li, W., Prampolini, G., Evangelisti, L., Uriarte, I., CaceLli, I., Melandri, S., Cocinero, E. J. 2019. «A General Treatment to Study Molecular Complexes Stabilized by Hydrogen-, Halogen-, and Carbon-Bond Networks: Experiment and Theory of $(\mathrm{CH} 2 \mathrm{~F} 2) n{ }^{\cdots}(\mathrm{H} 2 \mathrm{O}) \mathrm{m} »$. Angewandte Chemie - International Edition, 58, 8437-8442.

[14] Uriarte, I., Insausti, A., Cocinero, E. J., Jabri, A., Kleiner, I., Mouhib, H., Alkorta, I. 2018. «Competing Dispersive Interactions: From Small Energy Differences to Large Structural Effects in Methyl Jasmonate and Zingerone». Journal of Physical Chemistry Letters, 9, 5906-5914.

[15] Alonso, E. R., Kolesniková, L., Tercero, B., Cabezas, C., Alonso, J. L., Cernicharo, J., Guillemin, J.-C. 2016. «Millimeter Wave Spectrum and Astronomical Search for Vinyl Formate». The Astrophysical Journal, 832, 1-5.

[16] Drouin, B.Molecular Spectroscopy. Jet Propulsion Laboratory. California Institute of Technology, https://spec.jpl.nasa.gov/ftp/pub/catalog/catform. html (last time accessed: May 2, 2020).

[17] Endres, C. P., Schlemmer, S., Schilke, P., Stutzki, J., Müller, H. S. P. 2016. «The Cologne Database for Molecular Spectroscopy, CDMS, in the Virtual Atomic and Molecular Data Centre, VAMDC». Journal of Molecular Spectroscopy, 327, 95-104.

[18] Balle, T. J., Flygare, W. H. 1981. «Fabry-Perot cavity pulsed Fourier transform microwave spectrometer with a pulsed nozzle particle source». Review of Scientific Instruments, 52, 33-45.

[19] Brown, G. G., Dian, B. C., Douglass, K. O., Geyer, S. M., Shipman, S. T., PATE, B. H. 2008. «A broadband Fourier transform microwave spectrometer based on chirped pulse excitation». Review of Scientific Instruments, 79, 053103-1-053103-13.

[20] Ilyushin, V., Lovas, F. J. 2007. «Microwave Spectra of Molecules of Astrophysical Interest. XXV. Methylamine». Journal of Physical and Chemical Reference Data, 36, 1141-1276. 
[21] Young, S. H., Kukolich, S. G. 1985. «Microwave measurements and calculations of quadrupole coupling effects in CH3I and CD3I». Journal of Molecular Spectroscopy, 114, 483-493.

[22] Helminger, P., De Lucia, F. C., Gordy, W. 1971. «Rotational spectra of NH3 and ND3 in the 0.5-mm Wavelength Region». Journal of Molecular Spectroscopy, 39, 94-97.

[23] Gordy, W., C. De Lucia, F., Helminger, P. 1971. «Submillimeter-Wave Spectra and Equilibrium Structures of the Hydrogen Halides». Physical Review A, 3, 1849-1857.

[24] Alonso, E. R., León, I., Kolesniková, L., Alonso, J. L. 2018. «The Structural Signs of Sweetness in Artificial Sweeteners: A Rotational Study of Sorbitol and Dulcitol». ChemPhysChem, 19, 3334-3340. 